\title{
Secondary School English Teachers' Perception Towards The Use Of Flipped Learning In Buleleng Regency
}

\author{
D. K. Putri Handayani1 ${ }^{*}$, M. H. Santosa ${ }^{2}$, I N. P. Hadi Saputra ${ }^{3}$
}

123Jurusan Pendidikan Bahasa Inggris Universitas Pendidikan Ganesha

\section{A R T I C L E I N F O \\ Article history: \\ Received 22 February 2020 \\ Received in revised \\ Form 01 March 2020 \\ Accepted 18 April 2020 \\ Available online 30 May \\ 2020}

Keywords:

Perception, Flipped

Learning, ELT

\begin{abstract}
A B S T R A C T
This study is aimed at (1) investigating the perception of secondary school English teachers' perception towards the use of Flipped Learning in Buleleng regency, (2) observing the problems that the teachers encountered during implementing Flipped Learning, and (3) evaluating the solutions that the teachers do to solve the problems. This study was a mixed-method research design which used cross-sectional survey as the method. Purposive sampling was employed to four secondary English teachers who apply Flipped Learning. They came from three public secondary schools in Buleleng regency. This study used a questionnaire and an interview guide as instruments which had been tested for its validity and reliability. The data from the questionnaires were processed by using Arithmetic Statistics in Microsoft Office Excel to calculate the mean score in order to know the qualification level of each perception. The results of data analysis indicated that most of teachers corresponded to very positive perception on the use of Flipped Learning since the mean score was 81.25 which categorized to very high category. The results imply that Flipped Learning is highly recommended to be implemented in the English teaching and learning process.
\end{abstract}

\section{Introduction}

Stepping on $21^{\text {st }}$ century, technology is developing very fast. The development is integrated in many sectors including education. Technology also takes important role in Indonesian education system. Along with that phenomenon, the educators are also expected to improve their strategies and learning media by utilizing technology, as what the Permendiknas no. 16 tahun 2007 point 5 said that the educators are directed to master and implement ICT for the sake of learning. This previous statement is also emphasized by Rennie and Morrison (2013, p.16) they said that "Not only to master the new technologies, but also to understand and capitalize on the pedagogical implications". In examining such pedagogical implications, Blair, Maharaj, \& Primus (2015) found that, through the implementation of ICT, the focus of learning has moved from the 'traditional' teacher-centered to the student-centered learning.

According to Majid (2017) students-centered learning is a learning activity which allows the students to have more portions of control and role in learning process. By conducting student-centered learning, students can be more independent, active, and autonomous. Autonomy according to Harmer (2007) refers to the capability of students who can take their own way of learning by using their own skills and resources without teacher's guidance. However, because of the internet is very resourceful, then teacher's role is still needed by the students. In accordance with students' learning autonomy, the implementation of 2013 Curriculum also needs students to be independent in learning in terms of exploring the materials by their own.

In the context of ICT-based learning, nowadays teaching English as foreign language (TEFL) also starts implementing ICT which is integrated with the learning process particularly with the use of hybrid learning. Hybrid learning according to Buzzetto and Sweat (2006) is the blending of face-to-face and online learning. The delivery of curricular materials, access to resources, submission of assignments, project based learning, activities that support higher order thinking, and online discussions are involved to hybrid learning. Since the limitation of time that is given by the 2013 curriculum to the English teachers for teaching among the complexity of materials that they must complete during the semester, applying hybrid learning can be the best solution to overcome the problem. 
There are several types of hybrid learning which can be applied by the teachers; one of them is Flipped Learning. The term Flipped Learning means to 'flip' the instructions in the traditional classroom become online classroom, in short: the thing which is traditionally done in the classroom is now can be done at home, and the thing which is traditionally done as homework is now can be completed in the classroom (Bergmann and Sams, 2012).

Generally, Flipped Learning is quite similar with Flipped Classroom. The teachers may flip their class and let the students read the text, watching supplemental videos, and observe some slideshows or pictures outside the classroom, but to engage with Flipped Learning environment, they have to combine their practice with the Four Pillars of Flipped Learning. The involvement of those terms is then which differentiate between Flipped Learning and Flipped Classroom. According to Bergmann and Sams (2014) the four pillars of FLIP are, flexible environment, learning culture, intentional content, and professional educator.

Since the invention of Flipped Learning, it had been revealed by many studies in education, such as, Afrilyasanti, Cahyono, and Astuti (2017) who had conducted a research concerning on Indonesian EFL students' perception of Flipped Learning model. The result showed that by using Flipped Learning model, students were feeling helped to write better. Furthermore, Conner, Rubenstein, DiBendetto, Stripling, Roberts, and Stedman (2014) revealed that a Flipped Classroom approach seems to have promise as a model for delivering a teaching methods class to the Agricultural Teacher Education Program. Jaster (2017) had also conducted a study which concerned the students and instructor's perception of flipping college Algebra classroom to improve students' performance. The result of the study is the perception of students and instructor of using flipped college algebra classroom.

Flipped Learning becomes trending in education field. Not only in the overseas but Flipped Learning is also implemented in Indonesian EFL context especially in Buleleng regency, Bali. Currently, Santosa (2017) had conducted a study entitled Learning Approaches of Indonesian EFL Gen Z Students in a Flipped Learning context. He concerned on the higher education students' EFL learning quality through the use of Flipped Learning at English Language Education in one of university in Singaraja, Bali.

Noting to the phenomena, Flipped Learning is perceived able to develop the process of English learning in the school, yet based on the preliminary observation by conducting informal pre-interview, most of the secondary English teachers in Buleleng regency did not implement Flipped Learning yet. It is because some factors, such as; they do not know how to apply Flipped Learning or they cannot apply it because of the less of equipment in their schools. Regarding to the case, it is important to investigate the perception of the English teachers who applied Flipped Learning in their teaching process, also to investigate the problem they encountered during implementing Flipped Learning and how they coped with the problems. It is to examine whether Flipped Learning can give a good benefit like the previous studies or not, and the result will imply it is needed or not to implement Flipped Learning in Buleleng regency. Depending on the previous phenomena, the study is aimed at finding out the perception of secondary school English teachers' perception, the problems encountered, and the solution of problems towards the use of Flipped Learning in Buleleng regency.

\section{Methods}

This study used explanatory sequential mixed-methods design because the researcher collected quantitative data in the first phase, analyzed them and after that the result of the data were used to support the second, that was qualitative phase (Creswell, 2014). This design was used to answer three research questions, such as; first, to investigate the secondary school English teachers' perceptions on the use of Flipped Learning in Buleleng regency, second, to observe the problems that the teachers encountered during implementing Flipped Learning, and third, to evaluate the solutions which was given by the teachers to solve the problems.

The population of this study was the secondary schools' English teachers in Buleleng regency. The sampling technique used in this study was purposive sampling technique. According to Creswell (2012) in purposive sampling the individual and sites are intentionally selected as a sample to deepen the understanding of the central phenomenon. This sampling technique was chosen because the researcher already had the criteria for the data collection. The criteria should be the English teachers who already implemented Flipped Learning in their teaching process for more than a year. Based on preliminary observation in the form of informal interviews, four English teachers were selected to be the samples. They came from SMAN 1 Singaraja, SMAN Bali Mandara, and SMPN 1 Singaraja.

The instruments used in this study were close-ended questionnaire and open-ended interview guide. Meanwhile, smart recorder used for supporting the data collection. The questionnaires was designed by using five-point Likert scales which were suggested by McLeod (2008) and Vagias (2006) 
which consisted of 'strongly agree', 'agree', 'undecided', 'disagree', and 'strongly disagree'. Likert Scale was used to allow people give their assumption on particular thing whether they agree or not (McLeod, 2008). All of the respondents filled the questionnaire by putting 'check' $(\sqrt{ })$ mark on one of five response options for each item. All of the items in questionnaire were presented in Bahasa Indonesia. Meanwhile, the interview guide was consisted only six opening questions which were about the Four Pillars of FLIP and obstacles the teachers found implementing Flipped Learning, also the solutions they took to overcome the problems.

Content validity was conducted by giving the items of questionnaire to the expert judges. Then, the expert judges compared the items of questionnaire with the blueprint. Afterwards, the cross tabulation was analyzed by using Gregory's formula. The questionnaire consisted of 44 items. Based on the content validity testing, the result found that the content validity was 1 which was very high and it was recommended to be tried out.

$$
\begin{aligned}
\text { Content validity }= & \frac{D}{A+B+C_{44} D} \\
& =\frac{4+B+C+44}{A+B+} \\
& =\frac{44}{44}
\end{aligned}
$$

The questionnaire was tried out at one school namely SMAN Bali Mandara. The school was chosen because the teachers already implemented Flipped Learning in their classroom. The number of participant was three teachers. The number of participant was processed by using Pearson Product Moment counted in Microsoft Excel with the r-table was suited with the participant. The r-table for questionnaire of teachers with total number three was categorized by 0.997 (Priyanto, 2009). After the data had been calculated, the r-table result was 0.996917 . Depending on the $r$-table result, it was presented that there were 20 items valid and 24 items invalid. Finally, there were 20 items were left to be used to collect the data. The reliability was measured by Cronbach's Alpha in SPSS IBM Statistics 22.0. The result of Cronbach's Alpha significance was 0.994 . Depending on the $r$-table with distribution $5 \%$ and $N=4$, the value of $r$-table was 0.950 . Then, it could be concluded that Alpha $=0.950<$ r-table $=0.994$. It meant that the questionnaire was reliable and could be use to collect the data. The result can be seen in Table 1.

Table 1. Reliability of the Questionnaire

\begin{tabular}{lccr}
\hline & \multicolumn{3}{c}{ Reliability Statistics } \\
\hline Cronbach's Alpha & & N of Items & 20 \\
\hline
\end{tabular}

In this study, the data were analyzed in quantitative and qualitative ways. In quantitative way, the data were analyzed by using statistical analysis in Microsoft Excel. Each of five responses would have a numerical value which would be used to measure the perception from each statements (McLeod, 2008; Vagias, 2006). Based on five points of Likert Scale, the numerical value of each response was divided into two types; it stood for positive and negative statements. The elaboration can be seen in Table 2.

Table 2. The Numerical Value of Each Response in Five Points Likert Scale

\begin{tabular}{cccccc}
\hline \multirow{2}{*}{ Statement } & Strongly Agree & Agree & $\begin{array}{c}\text { Response } \\
\text { Undecided }\end{array}$ & Disagree & Strongly Disagree \\
\hline Positive & 5 & 4 & 3 & 2 & 1 \\
Negative & 1 & 2 & 3 & 4 & 5 \\
\hline
\end{tabular}

The result of the data were interpreted by determine the qualification level of each perception. The highest mean score corresponded to very positive, and the lowest mean score corresponded to very negative. The researcher used the qualification level suggested by Koyan (2012, pp. 24-25) in Table 3. 
Table 3. The Guidelines of Qualification Level

\begin{tabular}{cccc}
\hline No. & Interval & Categorization & Qualification \\
\hline 1 & $\mathrm{Mi}+1.5 \mathrm{SDi} \leq \mathrm{M} \leq \mathrm{Mi}+3.0 \mathrm{SDi}$ & Very High & Very positive \\
2 & $\mathrm{Mi}+0.5 \mathrm{SDi} \leq \mathrm{M}<\mathrm{Mi}+1.5 \mathrm{SDi}$ & High & Positive \\
3 & $\mathrm{Mi}-0.5 \mathrm{SDi} \leq \mathrm{M}<\mathrm{Mi}+0.5 \mathrm{SDi}$ & Average & Neutral \\
4 & $\mathrm{Mi}-1.5 \mathrm{SDi} \leq \mathrm{M}<\mathrm{Mi}-0.5 \mathrm{SDi}$ & Low & Negative \\
5 & $\mathrm{Mi}-3.0 \mathrm{SDi} \leq \bar{X}<\mathrm{Mi}-1.5 \mathrm{SDi}$ & Very low & Very Negative \\
\hline
\end{tabular}

(Adopted from Koyan 2012, pp. 24-25)

Meanwhile, the qualitative data which was gained from the result of interview were analyzed by using Systematic of Data Analysis from Miles \& Huberman (1994). There are four steps of the data analysis presented by Miles and Huberman, it includes data collection, data reduction, data display and conclusion drawing/verifying. In data collection, after the respondents had done to fill the questionnaire, the next step was obtaining the data from interview. Interview guide was used to make the questions were more organized in order to get the answer needed. During interviewing the interviewees, voice recorder was used by the researcher. At the end of the process, the researcher transcribed the result of the interview. In data reduction phase, the collected data were selected, filtered, and simplified, based on the focus of the study and what the researcher needed. Relating to this study, the researcher listed all of the transcriptions of the interviews about the teachers' perception towards the use of Flipped Learning into several codes based on the dimensions of the interview guide; each of the four respondents were coded as 'R1', 'R2', 'R3', and 'R4', while flexible environment was coded as 'FE', learning culture was coded as 'LC', intentional content was coded as 'IC', professional educator was coded as 'PE', obstacle was coded as 'Obs', and solution was coded as 'Sol'. Then, the unneeded data were cut down and leaved the required data. After that, the data were coded again until very saturated and could be used to answer the second and third questions of research question. After the data reduction were gotten, then the data were displayed. In this stage, the data display helped the researcher drew final conclusions about how was the teachers' perception about Flipped Learning, what kind of problems that they encountered, and how they solved the problems while implementing Flipped Learning. The data from questionnaires were displayed by tables and chats, while the data from interview were displayed descriptively. In conclusion drawing and verification, the researcher drew final conclusion to answer the research problem. Verification was done by relating the finding with the literature review.

\section{Result And Discussion}

Regarding to the result of the secondary school English teachers' perception on the use of Flipped Learning in quantitative side, the respondents had expressed a very positive perception on the use of Flipped Learning which was indicated by a very high mean score of the questionnaire result, it was 81,25 and it is in interval 79.99 $\leq \mathrm{M} \leq 99.99$. The categorization can be seen in Table 4.

Table 4. The Categorization of Mean Score of Secondary School English Teachers' Perception on the Use of Flipped Learning

\begin{tabular}{clccc}
\hline No & \multicolumn{1}{c}{ Criteria } & Interval & Categorization & $\begin{array}{c}\text { Qualificat } \\
\text { ion }\end{array}$ \\
\hline 1 & $\mathrm{Mi}+1.5 \mathrm{SDi} \leq \mathrm{M}<\mathrm{Mi}+3.0 \mathrm{SDi}$ & $79.99 \leq<99.99$ & Very High & Very Positive \\
2 & $\mathrm{Mi}+0.5 \mathrm{SDi} \leq \mathrm{M}<\mathrm{Mi}+1.5 \mathrm{SDI}$ & $66.67 \leq<79.99$ & High & Positive \\
3 & $\mathrm{Mi}-0.5 \mathrm{SDi} \leq \mathrm{M}<\mathrm{Mi}+0.5 \mathrm{SDI}$ & $-53.33 \leq<66.67$ & Average & Neutral \\
4 & $\mathrm{Mi}-1.5 \mathrm{SDi} \leq \mathrm{M}<\mathrm{Mi}-0.5 \mathrm{SDI}$ & $-39.99 \leq<-53.33$ & Low & Negative \\
5 & $\mathrm{Mi}-3.0 \mathrm{SDi} \leq \bar{X}<\mathrm{Mi}-1.5 \mathrm{SDI}$ & $-20.01 \leq<-39.99$ & Very Low & Very negative \\
\hline
\end{tabular}

In short, all percentages of secondary school English teachers' perception on the use of Flipped Learning in Table 4 were transformed into Diagram 1. 


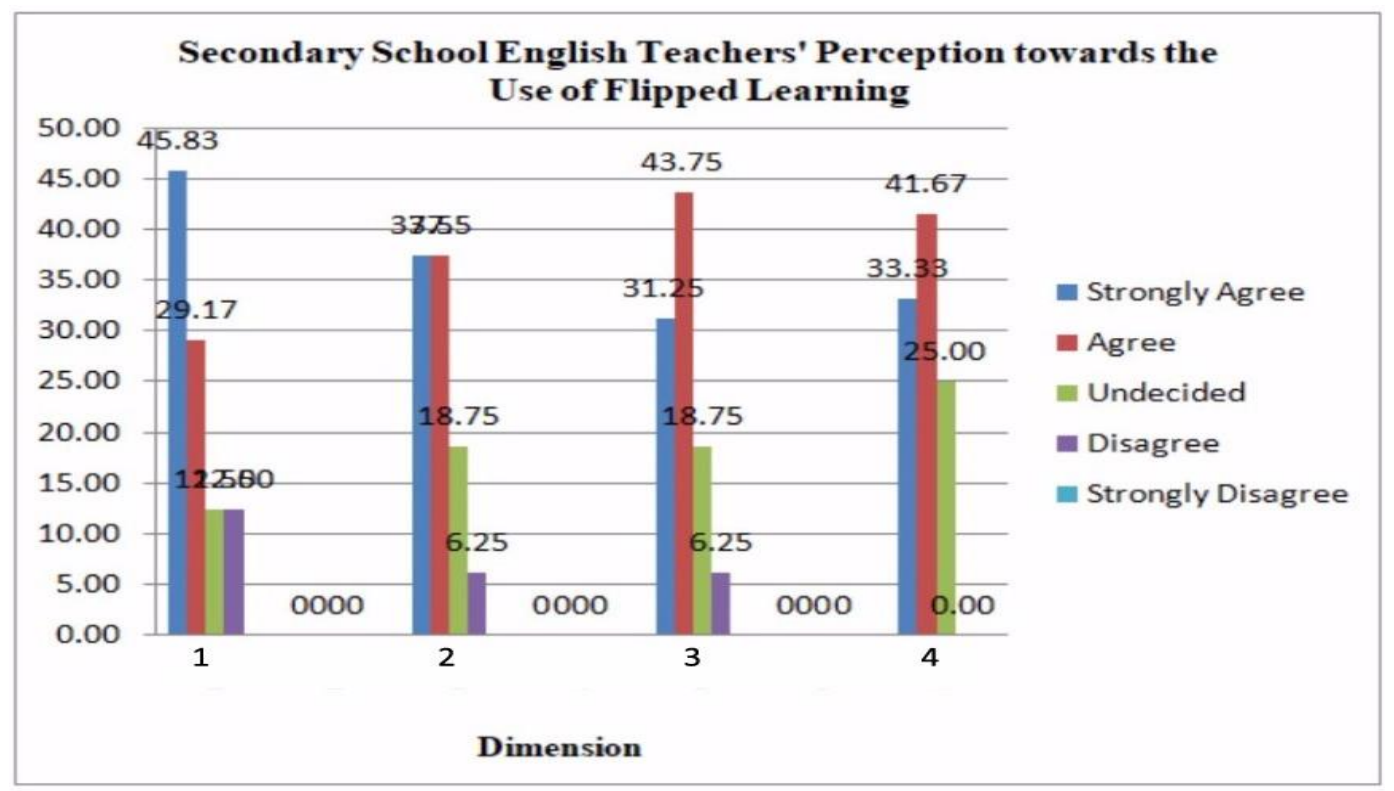

Figure 1. Diagram The Percentage of Secondary School English Teachers' Perception towards the Use of Flipped Learning

Regarding to the result of the study which had been presented in findings, it indicated the same result as the previous study which was conducted by Cheok, Wong, Ayub, Mahmmud (2017) who examined the secondary teachers' perception on e-learning in Malaysian Secondary School. The teachers perceived that e-learning was beneficial for the learning process because it made their job became easier rather than doing traditional teaching approach. The e-learning system also had helped them to organize the teachers' teaching and learning materials. The advantages of e-learning (Flipped Learning) were also felt by the secondary English teachers in Buleleng regency. One of the respondents said that Flipped Learning was good to be implemented in 2013 curriculum since the time allotment of English subject was decreased for senior high school; it means that the teacher only has limited time to deliver materials which is complex. Therefore, the issue demanded the teacher to find a solution to solve the problem. Nowadays, the existence of Flipped Learning had worked the problem out. Regarding to the research questions, there were three research questions presented. First, how the secondary school English teachers in Buleleng perceive about the use of Flipped Learning; second, what kind of problems do the secondary school English teachers encounter when implementing Flipped Learning, and; third, how the secondary school English teachers solve the problem when implementing Flipped Learning.

In the research question one, the result of the questionnaire were divided into 4 dimensions, such as; flexible environment, learning culture, intentional content, and professional educator. Furthermore, the result of the questionnaire was supported by the qualitative data in the form of interview result which also examined about the Four Pillars of FLIP.

Firstly, in flexible environment, the result of the questionnaire showed that the respondents perceived in a very high categorization since the mean score was 24.5 and it corresponded to as very positive perception. Related to the theory stated by Broodryk (2016) that a Modern Learning Environment (MLE) is able to engage a number of different types of spaces, such as; classrooms, breakout spaces, laboratories, performance spaces, and so on, and the environment is one that is adequate to extend and adapt as the development and the changing of educational practices. This theory was also supported by Osborne (2013) who said that MLE is able to facilitate the traditional pedagogies, for example, direct instruction, but there are also the typical offers for the teachers and students, such as, flexibility, openness, and access to resources.

This theory was also promoted by empirical study examined by Chang (2016) in his study about how he used Flipped Learning to inform his teaching implied that the result of FLIP survey already gave him more information to improve the use of Flipped Learning for his students to build their own knowledge. The result was also supported by the respondents' opinion during interview section, as what had been said by R4 that flexible environment made 'the walls' were coming down. It meant that the students were not only sitting passively in the classroom but they were also able to study everywhere, anytime, and with everyone as they broke their own 'walls' in learning. 
Secondly was about learning culture. In quantitative result, the respondents showed a high perception on this dimension with the result of mean score was 16.24 and it corresponded to positive perception. But, there is uniqueness found between the third and forth scales, which is "undecided" is higher than "disagree". It is because the respondents have different point of view from the items presented, so that they choose undecided because they cannot fit their choice on the items. The term learning culture was aiming to make the students were being autonomous in learning or was known as student-centered learning. Santosa (2017) had conducted a study on Indonesian EFL Gen Z students' learning approach in the context of Flipped Learning. Related to the empirical study stated by Santosa, this theory was supported by Suharmanto (2003) who said that teaching and learning processes should emphasize on accommodating students in order to be self-directed and autonomous rather than being passively sitting in the classroom. Actually, Flipped Learning had been a link to connect the students to a learner-centered classroom environment which was expected by the teachers for enabling deeper learning (Bergmann and Sams, 2012).

Those statements were also promoted by the perception of the respondents in learning culture, R1 gave his opinion that the teacher should give a 'fishhook' to the students by asked them to explore the material through the internet by giving a link which was connected to the topic needed and students learn whether from online or offline so that students could be autonomous. The supporting answer was started by R3 that LC played an important role to build the students' autonomy in learning. It was continued by R2 who said that by implementing LC, students had prepared themselves if the teacher could not attend the class because the material had been uploaded to the platform by the teacher so that students could independently access the material and complete the task without teacher's guidance.

The third one was intentional content. The result of quantitative value of this dimension was the same as learning culture; it was in high category with the mean score was 16 and corresponded to positive perception. Uniqueness is also found between the third and forth scales, which is "undecided" is higher than "disagree". It is because the respondents have different point of view from the items presented, so that they choose undecided because they cannot fit their choice on the items. The term intentional content was having a meaning as any kind of materials which the teachers should deliver to the students and what they had to explore by their own (Bergmann and Sams, 2014). It means that teachers should not deliver the whole of the materials to the students, or in short, students should complete the materials by exploring the rest by their own.

The theory was supported by Rebecca (2009) who held a study which was investigating on Let Me Learn Process in the mean of intentional teaching and learning. This study concerned at teachers who received training in the Let Me Learn program and the output of the training was used to teach intentionally and to help children develop into intentional learners by stimulating in them the skills of meta-awareness, meta-cognition, and reflection. According to Johnston (1998) LML carried out the important of 'listening to their voice of learning' since it was the key to unlock the students' willingness to learn.

The result and the related theory were also supported by the interview result. Depending on the respondents' perception on intentional content, R3 shared his opinion about IC that the teacher provided the main topic of material and the students needed to find the additional information of the material for more. The teacher also only explained the outline of the material first and then it was the students' responsibility to explore more by themselves. The statement was also supported by R1 who said that the teacher provided the students with link or website and they were directed to watch video about the material on YouTube to stimulate their willingness to study. Furthermore, R2 implemented IC as the preparation for the students to face final exam, so that students were given many exercises to be solved in order they could pass the exam with a good result.

The fourth dimension was about professional educator. The respondents showed a very positive perception with the result of mean score was 24.5. The perception was in similar category with the first dimension. In this dimension, there is also uniqueness found between the third and forth scales, which is "undecided" is higher than "disagree". It is because the respondents have different point of view from the items presented, so that they choose undecided because they cannot fit their choice on the items. The term professional educator meant how the teachers maintained the students with innovative way for engaging them to the learning process. Since Flipped Learning was the learning approach which used by the teachers to answer the challenge of $21^{\text {st }}$ century, both teachers and students should equip themselves with materials and skill in operating ICT devices in order to bring them into the learning (Santosa, 2017). The related theory from Santosa was also supported by Hall and Langdon (2006); Kane and Mallon (2006) who emphasized that the main intention for being a teacher was the willingness to make a difference to the life outcomes of the learners. 
The empirical study examined by Timperley, Wilson, Barrar, and Fung (2007) obtained that the chance for teachers to engage in professional learning and development could have a high impact on student learning. Depending on the interview result, the respondent had expressed their insight about this term. R1 showed his professionalism by autonomously equip himself with Flipped Learning skill and seeking the information from the other educators who used the same learning approach in order to make a comparison about the strategy between one and another. In another way, R2 built a peer-teaching among the students by means engaging one or more students who had higher capabilities than the others to guide them in learning. Another way was also attempted by R3 who always engaged to the discussion section whether in online and also in the classroom in order the R3 could know the students' learning development.

During implementing Flipped Learning, each of the respondents had struggled with many obstacles. Most of the respondents implied that similar obstacles such as, the obligation of the school which was banned the students to bring gadgets, academic dishonesty among students, and students ability to operate computer or to work in platform. Noting to the obligation, it was the same as the previous study which was stated that there was the gap between what students can do with technology and what they were permitted to do with technology in their school (Cheok et al. 2017). It caused the teachers were difficult to implement Flipped Learning well. The existing empirical study was also supplemented by the result of the interview, such as from R2 and R3 who had the problem abot regulation in his school for using ICT devices.

Secondly, academic dishonesty was occurred because of the students were directly connected with the internet which provided many resources that spoiled their willingness to work on themselves. Thus, they were hooked to do plagiarism. It was related to the study held by Hosny and Fatima (2014) about the students' attitude towards cheating and plagiarism who obtained that both cheating and plagiarism were common for the students, despite the fact that most of them believed that they were unethical and against the religious values. The similar study was also conducted by Sorea (2011) who presented the topic about factors that influenced students' attitude on copying and plagiarism. The result found that most of the plagiarism occurred because of the existing of the internet and the students were not explained about the disadvantages for doing plagiarism. The result of the interview data also supported this finding as what had said by R1 and R3 that the students were sometimes dishonest when doing the task. Most of them did copy-paste from the internet.

Lastly was the lack of knowledge of using ICT devices especially computer or laptop. Brush, Glazewski and Hew (2008) have implied that ICT was used as equipment for students to explore learning topics, solved problems, and provided solutions to the problems in the learning process. But in fact, the teachers realized that not all of the students came from family with a high economic status, meant that not all of students had computer or laptop at their home. It leaded to the lack of skill of using those kinds of ICT devices.

This phenomenon was supported by the related empirical literature which was presented by Fu (2013) who conducted a study about the barriers encountered towards the use of ICT in the school. This study was concerning about the point of view from the teachers and the school infrastructure, but still had connection to the context of lack in using ICT. Some of the barriers were about the lower of expectation and motivation using ICT, time limitation, lack of innovation to integrate learning with ICT, and so on.

Regarding to the existing theory and empirical study, the result of the interview was also presented the same issue, as had been said by R4 who encountered problems from the students. It was rather difficult for R4 to manage the students of grade 10 because they were not capable yet to adapt with Flipped Learning because some of them did not have background knowledge about computer and lack of knowledge in operating ICT devices. R4 often found some of them were still typing with 14 fingers (red: tujuh tujuh) meant they only used their index fingers to type on the keyboard.

From those issues, the respondents tried to find a way out from the problems. For the obligation problem, R2 provided a solution to ask permission to the headmaster for using gadget in the classroom for the sake of learning only as well as made an agreement with the students to do so. For the academic dishonesty, R1 and R3 agreed to give a small punishment for those had done plagiarism by announcing their names in front of the class for them to get shame and asked them to recreate the tasks, so that they would not repeating their mistake. The last solution for the lack of skill in using ICT was solved by R4 by accompanying the students almost all the time to train them in operating ICT devices.

The discussion concludes that the secondary school English teachers perceive a very positive perception on the use of Flipped Learning. There are also some obstacles which the teachers encountered during applying Flipped Learning, such as; obligation by school, commitment by students, facilities and infrastructure, skill, and integration by students. The teachers also have strategies how to solve the problems, among others; asking permission from the headmaster for the students that they can bring their 
gadgets to classroom for the sake of learning, giving punishment for those who did the plagiarism, inviting and allowing the students who do not have computer or laptop to the Computer Laboratory and Library, accompanying and guiding the students who are not capable yet in operating ICT devices, and asking the students to finish their tasks in online continuously as their commitment to the teachers.

Depending on the findings of the study, there are some implications which can be revealed from this study. Since the teachers had a very positive perception on the use of Flipped Learning, it implies that it is needed to implement and develop more about Flipped Learning not only for those who have applied but also for the other schools which do not apply it yet. It is important to apply Flipped Learning because according to Horn \& Staker (2011) by 2019, 50 percent of all high school subjects will be predicted to be delivered using online format. He also said that the education will be transformed by making it is easy to be accessed and individualized.

Theoretically, this study implies the development of the theory from the previous studies and also broadens the resources of related studies ahead for those who want to conduct the same topic. Practically, Flipped Learning helps the teachers to develop their teaching skill as they make an innovation in teaching and learning especially for the teaching strategy and in making media. Teachers are also helped by the flexibility of place and time as they can teach everywhere and anytime. Moreover, if they cannot attend the class, they no need to be worried because the materials have uploaded on the platform and the students can access them easily.

\section{Conclussion}

Based on the discussion and result of the study above, it can be concluded that; the secondary school English teachers perceived a very positive perception on the use of Flipped Learning; there were some obstacles that the teachers encountered during implementing Flipped Learning, such as: commitment, skill, facilities and infrastructure, and integrity of using Flipped Learning; there were some solutions that the teachers did to overcome the obstacles, among others: giving the students additional time to complete the task, giving punishment for those who did the academic dishonesty, guiding the students who were lack of skill in operating ICT devices, asking permission to the headmaster and making agreement with the students to use gadgets only for the sake of learning, and asking the students to continuously being active in the learning process.

\section{Reference}

Afrilyasanti, R. (2017). Indonesian EFL Students' Perceptions on the Implementation of Flipped Classroom Model, 8(3), 476-484.

Bergmann, J., Sams, A. (2012). Flip your classroom: Reach Every student in every class every day. Washington: International Society for Technology in Education.

Bergmann, J., Sams, A. (2012). 7 things you should know about... Flipped classrooms. Educause Learning Initiative. Retrieved from https://net. educause.edu/ir/library/pdf/ELI7081.pdf

Blair, E., Maharaj, C., \& Primus, S. (2015). Performance and perception in the flipped classroom. https://doi.org/10.1007/s10639-015-9393-5

Broodryk, J. (2016). Pedagogies that support Flexible Learning Environments.

Brush, T., Glazewski, K. D. and Hew, K. F., 2008. Development of an instrument to measure preservice teachers' technology skills, technology beliefs, and technology barriers. Computers in the Schools, vol. 25, pp.112-125.

Buzzetto, N. A. (2006). Hybrid Learning Defined. Journal of Information Technology Education. Adapted From: Incorporating the Hybrid Learning Model into Minority Education at a Historically Black University Published in the Journal of Information Technology Education, Volume 5.

Cheok, M. L., Wong, S. L., Ayub, A. F., \& Mahmud, R. (2017). Teachers ' Perceptions of E-Learning in Malaysian Secondary Schools, 5(2), 20-33. 
Chang, Sau Hou. (2016). How I used flipped learning to inform my teaching? Association of Teacher Educators Conference Louisville, KY. Indiana University Southeast.

Conner , N. W., Rubenstein, E. D., Di Benedetto, C. A., Stripling, C. T., Roberts, T. G., \& Stedman, N. L. P. (2014). Examining Student Perceptions of Flipping an Agricultural Teaching Methods Course. Journal of Agricultural Education, 55(5), 65-77. https://doi.org/10.5032/jae.2014.05065

Creswell, J. W. (2012). Survey design. In Educational research: Planning, conducting, and evaluating quantitative and qualitative research (4th ed., p. 386). Boston, the United States of America: Pearson Education, Inc.

Creswell, J. W. (2014). The selection of a research approach. In Research design qualitative, quantitative, and mixed methods approaches (4th ed., pp. 41-42). the United States of America: SAGE Publications, Inc.

Fu, Shan Jo. (2013). ICT in Education : A Critical Literature Review and Its Implications, 9(1), 112-125.

Hall, D. \& Langton, B. (2006). Perceptions of the status of teachers. Wellington: Ministry of Education and New Zealand Teachers Council.

Harmer, Jeremy. 2007a. The Practice of English Language Teaching. Malaysia: Pearson Education Limited.

Horn, M. B., \& Staker, H. (2011). The rise of K-12 blended learning. Innosight Institute.

Hosny, Manar., Fatima, Shameem. (2014). Attitude of Students towards Cheating and Plagiarism: University Case Study. College of Computer and Information Scieces, King Saud University, Riyadh, Saudi Arabia.

Jaster, R. W. . (2017). Student and Instructor Perceptions of a Flipped College Algebra Classroom. International Journal of Teaching \& Learning in Higher Education, 29(1), 1-16. Retrieved from http://ezp.waldenulibrary.org/login?url=http://search.ebscohost.com/login.aspx?direct=true\&d $\mathrm{b}=$ eue $\& A N=122365735 \&$ site $=$ eds-live $\&$ scope $=$ site

Johnston, C.A. (1998). Let Me Learn. Thousand Oaks, CA: Corwin Press.

Kane, R. \& Mallon, M. (2006). Perceptions of teachers and teaching. Wellington: Ministry of Education and New Zealand Teachers Council.

Koyan, I. W. (2012). Statistik pendidikan teknik analisis data kualitatif. Singaraja: Undiksha Press.

Majid, A. N. (n.d.). The Use of Information Technology in Teaching English: An Attempt to Develop Student-Centered Learning at Telkom Polytechnic.

McLeod, S. A. (2008). Likert scale. Retrieved from www.simplypsychology.org/likert-scale.html.

Miles, M.B., \& Huberman, A. M. (1994). Qualitative data analysis. Thousand Oaks: Sage.

Osborne, M. (2013). Modern Learning Environments. CORE Education “White Paper”.

Priyatno, D. (2009). 5 Jam belajar olah data dengan SPSS 17. Yogyakarta: Andi.

Rebecca, T. (2009). The Let Me Learn Process : An Agent for Intentional Teaching and Learning Tabone Rebecca A Dissertation Presented to the Faculty of Education in Part Fulfilment of the Requirements for the Degree of Bachelor in Education, (May).

Rennie, F., \& Morrison, T. (2013). E-learning and social networking handbook: Resources for higher education.New York: Routledge. 
Santosa, M.H. (2017). Learning approaches of Indonesian EFL Gen Z students in a Flipped Learning context. Retrieved from https://www.researchgate.net/publication/320171031

Sorea, D. (2017). Factors that Influence Students ' Attitude Towards Copying and Plagiarism. Universitatea Transilvania Brasov.

Suharmanto. (2003). Learning autonomy: A way to improve English language teaching (ELT) in Indon esia. TEFLIN Journal, 14(1).

Timperley, H., Wilson, A., Barrar, H., \& Fung, I. (n.d.). Teacher Professional Learning and Development.

Vagias, W. M. (2006). Likert-type scale response anchors. Clemson International Institute for Tourism \& Research Development, Department of Parks, Recreation and Tourism Management 